\title{
NARCOTIC DRUG LAWS AND ENFORCEMENT POLICIES
}

\author{
Rufus KING*
}

The King's argument was that anything that had a head could be beheaded, and that you weren't to talk nonsense.

The Queen's argument was that, if something wasn't done about it in less than no time, she'd have everybody executed, all round. . . .

Lewis Carroll, Alice's Adventures in Wonderland

Repressing the narcotic drug traffic by criminal sanctions is a comparatively recent innovation in the United States. Addicted persons have enjoyed the appellation "dope fiend" for only some forty years, ${ }^{1}$ while the "pusher" of pre-World-War-I society was usually the local pharmacist, grocer, confectioner, or general-store-keeper." In fact, until the turn of the twentieth century, the use of opium and its derivatives was generally less offensive to Anglo-American public morals than the smoking of cigarettes. ${ }^{3}$

In many significant features, the patterns we have evolved to deal with this problem are atypical. First, the problem itself is viewed by most other civilized nations as one involving health rather than criminality, and it is virtually nonexistent in the view and experience of some. Moreover, although the ingestion and injection of narcotic substances seem patently to be matters primarily of local concern, the federal government has innovated our repressive policies, almost sua sponte, and a federal agency has been the dominant enforcement instrument from the very outset; even the initial impetus came, in part at least, from a treaty commitment undertaken by the federal government-far removed from considerations of state police power or local public policy. Furthermore, Congress has never, before or since, relied upon the federal tax laws to achieve an objective so remotely connected with the collection

- A.B. 1938, Princeton University; LL.B. 1943, Yale University. Member of the New York, Maryland, and District of Columbia bars. Chairman, Committee on Narcotics and Alcohol, Section of Criminal Law, American Bar Association. Counsel, Senate Crime Commission, I951; Senate Committec on Crime and Law Enforcement in the District of Columbia, 1953. Contributor to legal periodicals.

${ }^{1}$ An early epithet, reflecting the fact that Civil War veterans had become addicted in large numbers as a result of battleground medication, was "the army disease." See DAvid W. MAURER AND VICTOR H. Vogel, Narcottcs and Narcottc Addiction 6, (1954). Cf. Interdepartmental Committee on Narcotics, Report to the President 4 (1956).

${ }^{2}$ See Kolb, Let's Stop this Narcotics Hysteria, Saturday Evening Post, July 28, 1956, p. x9; CharLes E. Terry and Mildred Pellens, The Opium Problem, 7, 23, et passim (1928); Maurer and Voger, op. cit. stipra note I, at 9-I9; Stevens, Make Dope Legal, Harper's Magazine, Nov. 1952, pp. 40, 4r.

'In the $x 870^{\prime}$ 's and $80^{\prime}$ 's, medical men were beginning to warn that opium addiction was claiming people "who crave the effect of a stimulant, but will not risk their reputation for temperance by taking alcoholic beverages," and who "have not come from the ranks of reckless men and fallen women, but the majority of ... [whom] are to be found among the educated and most honored and useful members of society." TERry \& Pellens, op. cit. supra note 2, at 8, 17. 
of revenues, ${ }^{4}$ and no comparable law-enforcement assignment (disregarding the troublesomely analogous Prohibition experiment) has ever been given to the Treasury Department.

Most notably unusual, however, this chronicle of federal intervention is an epoch of dismal failure. Congress has expanded the list of federal crimes in support of local enforcement efforts a dozen times in the last half century, and with no other exception (again, omitting the Volstead Act), the results have been salutary: federal intervention has caused the problem to diminish or disappear. ${ }^{5}$ But this has not been true of the illicit drug traffic: the costs of drug-law enforcement have increased steadily, ${ }^{\circ}$ and though estimates of our addict population are manipulatible in a wide range, no one suggests that addiction has ever shrunk to negligible proportions or ceased to be widespread. . An addict cut off from his supply for a few days "kicks the habit"; so the mere survival of this substantial community of "users" over the yearsover forty years-is unanswerable proof that illicit traffickers have never been deterred from meeting the addict's needs. ${ }^{8}$

The United States adhered to the Hague Opium Convention of 1912, by which it undertook to control the domestic production, sale, use, and transfer of opium and coca products. ${ }^{9}$ Since, however, neither opium poppies nor coca shrubs were being grown extensively in this country, our undertaking to curb production was a mere

"Other comparable regulation-by-taxation measures now on the federal books are: Act of July I3, . 1866, 14 STrT. 136, 26 U. S. C. $\$$ I900 (1952) (obligations of nonnational banks); Act of Aug. 27, 1894, 28 SтAт. 562, 26 U. S. C. $\$ 1807$ (1952) (playing cards); Act of Aug. 11, 1916, 39 STAT. 476, 26 U. S. C. $\$ 1920$ (1952). (cotton futures); Act of July 10, 1930, 46 STAT. 1022, 26 U. S. C. $\$ 2300$ (1952) (oleomargarine); Act of, May ro, 1934, 48 STAT. 763, 26 U. S. C. $\$ 2470$ (1952) (vegctable oils); Act of June 26, 1934, 48 STAT. 1240, 26 U. S. C. $\$ 2700$ (1952) (firearms); Act of Jan. 2, 1951, 64 Star. II34, I5 U. S. C. $\$ \$$ II7I, II72 (1952) (slot machines).

${ }^{5}$ E.g., Act of July I, 1902, 32 STAT. 727, 18 U. S. C. $\$ 1991$ (1952) (train robbery); Act of June 25, I910, 36 STAT. 825 , I8 U. S. C. $\$ 43$ (1952) (white slavery); Act of June 22, 1932, 47 STAT. 326 , 18 U. S. C. $\$ 120$ (1952) (kidnapping). Nearly all these statutes spring from the federal commerce power and appear in the Federal Criminal Code; and responsibility for their enforcement falls on the Department of Justice. See King, The Control of Organized Crime, 4 Stan. L. Rev. 52, 53 n. 7 (195I).

- Appropriations for narcotic drug law enforcement at the federal level have averaged $\$ 1,623,892$ annually for the period $1930-55$. This reflects a decline from $\$ 1,574,154$ in 1930 to $\$ 1,249,470$ in 1936 , and then a steady rise to $\$ 1,327,000$ in $1944, \$ 1,647,000$ in $1950, \$ 2,790,000$ in 1953 , and $\$ 2,990,000$ in 1955. Hearings before the Subcommittee on Improvement in the Federal Criminal Code of the Senate Committee on the Judiciary, 84th Cong., Ist Sess. pt. $x$, at 12 (1955).

The most popular current figure is 60,000 addicts, or one person in every 3000 . Sec INTERDEPARTarental Commitree on Narcotics, op. cit. supra note $\mathrm{I}$, at 8; Senate Committee on the Judiciary, The Illicit Narcotics Traffic, S. REP. No. 1440, 84th Cong., 2d Sess. 3 (1956).

8 The illicit traffic is supplied almost entirely by smuggling operations, and preventive efforts at critical points-i.e., ports of entry-are left to the Bureau of Customs. Sec Hearings, supra note 6, pt. I, at 87. Commissioner of Narcotics Anslinger has characterized the activities of his enforcement staff (then I 88 agents) as "like [using] a piece of blotting paper to mop up the occan." Hearings before the Senate Special Committee to Investigate Organizd Crime in Interstate Commerce, 82d Cong. Ist Sess. pt. 14 , at 430 (1951). See also note 42 infra.

${ }^{\circ}$ Suppression of the Abuse of Opium and Other Drugs, Convention and Final Protocol Bctween the United States and Other Powers, Jan. 23, I912 and July 9, I913, 38 Srat. 1912, T.S. No. 612. Bilateral treaties curbing the exploitation of the opium traffic by American nationals had been negotiated at carlicr dates, beginning with a United States-Siam pact in 1833 . Treaty of Amity and Commerce, March 20, I833, art. 2, 8 STAT. 454, T. S. No. 32I. See Wright, The International Opittm Commission, 3 J. INT'L L. 648 (1909). 
formality, apparently agreed upon to encourage countries which were producers to join in restricting supplies in the world market. ${ }^{10}$ There was, of course, perfect logic in our pursuit of this aim: if we could have induced all nations where raw drugs might be grown to clamp on tight controls, our domestic traffic, dependent on smuggling, would long since have disappeared. We have remained staunch in our support of international action to control supplies, adhering to subsequent conventions, ${ }^{11}$ and working diligently through the League of Nations, the United $\mathrm{Na}$ tions, and the autonomous Permanent Central Opium Board. ${ }^{12}$ Most recently, we have been promoting the idea of an International Opium Monopoly, with plenary powers of inspection and control. ${ }^{13}$

But American efforts to induce other nations to forego the production and marketing of drugs, so as to rid us of the illicit importer, have never borne much fruit. ${ }^{14}$ Our friends have been apathetic, ${ }^{15}$ and our cold-war enemies have been flatly un-

${ }^{10}$ The principal sources of opium are countries of the Eastern Mediterranean, Asia, and Asia Minor -currently Iran, Yugoslavia, India, and Turkey; coca, indigenous to the west coast of South America, is also grown in Indonesia.

${ }^{11}$ The Geneva Convention of 1925 (International Opium Conference, Feb. 19, I925, L.N.T.S. No. 1845) set up the first administrative machinery to gather statistical material and recommend quotas for the export and import of narcotic drugs; the Geneva Convention of 1931 (Limiting the Manufacture and Regulating the Distribution of Narcotic Drugs, Convention and Protocol of Signature Between the United States and Other Powers, July 13, I93 T, 48 STAT. 1543, T.S. No. 863) sought to make the quota controls mandatory and otherwise to tighten the curbs on domestic processing and transfers; the Protocol of 1946 (Protocol Between the United States of America and Other Governments, Narcotic Drugs, 6I STAT. 2230, T.I.A.S. No. I67I) brought the prior conventions into the framework of the United Nations and established the United Nations Commission on Narcotic Drugs; the Protocol of 1948 (Entry into Force of Amendments Set Forth in the Annex to the Protocol of Dec. II, I946, Narcotic Drugs, Mar. 30, 1948, 62 STsт. 1796, T.I.A.S. No. 1859) provided for the extension of existing controls to new drugs and derivatives found by the World Health Organization to be dangerously addicting; and the Protocol of 1953 (Protocol for Limiting and Regulating the Cultivation of the Poppy Plant, the Production of, International and Wholesale Trade in, and Use of Opium, June 23, I953, U.N. Pub. Sales No. 1953, XI.6) restricted opium production to certain designated countries and further limited the distribution and use of opium products. An additional convention, proposed in 1936 , makes narcotic drug offenses extraditable and compels signatory powers to treat certain proscribed acts as crimes-i.e., creates new categories of crime directly by international agreement; this has been ratified by a score of countries, but the United States is not a party. Elsewhere in this symposium, the objectives, mechanics, and effectiveness of international narcotic drug controls are explored more extensively. Renborg, International Control of Narcotics, supra 86-112.

12 See Harry J. Anstinger and William F. Tongrins, The Traffic in Narcotics 39-4I (i953).

${ }^{13}$ Bureau of Narcotics, U. S. Treasury Dep't, Traffic in Opium and Other Dangerous Drugs I (1950); id. at I (1951); id. at 2-3 (1952).

${ }^{14}$ See Comment, Narcotics Regulation, 62 YALE L. J. 751, 763-65 (1953).

15 The Bureau of Narcotics often uses its annual report to disseminate statements of censure against nations whose repressive efforts appear wanting in zeal. Thus, in 1950, Bolivia and Peru were prodded to eradicate the practice of chewing coca leaf among their citizens; it was noted that the British were still making "efforts" to abolish opium smoking in their Far East territories; Thailand and Indonesia were "called on to explain" their policies in operating government opium shops; and Italy and Turkey were noticed as among the foremost suppliers of drugs for the American traffic. Burfav of Narcortcs, op. cit. supra note 13, at 2-4 (195I). In I95I, Iran was disclosed to have permitted 333 tons of opium to have "disappeared," a situation characterized by the Permanent Central Opium Board as "most disquieting." Id. at 4 (1952). In 1955, the situation in Thailand was reported to be "less than satisfactory" and in need of "more strenuous efforts"; there were also "disturbing reports" about cocaine manufacture in Bolivia, Ecuador, and Peru; and it was noted that the situation in Lebanon "remains unsatisfactory and requires far greater efforts to reduce the illicit traffic." Id. at 2-3 (1956). It is significant that the Protocol of I953, supro note II, still lacks ten adherents to reach the number of twenty-five required to make it effective, and that none of the opium-producing countries have become parties. 
cooperative. ${ }^{16}$ Excepting the duration of World War II, when many opium-producing countries were cut off and travel restrictions put most smugglers out of business, narcotic drugs have continued to flow freely into our illicit market. ${ }^{17}$

A more significant aftermath of our participation in the 1912 convention was the Harrison Act, ${ }^{18}$ passed by the Sixty-third Congress principally to comply with our undertaking to control the domestic sale, use, and transfer of opium and coca products. ${ }^{19}$ This act has provided the basis for domestic law enforcement, vis-à-vis the illicit drug traffic, ever since its enactment. As has been observed, it is not a forthright criminal statute, but rather a regulatory measure in the ill-tailored guise of a federal revenue enactment. ${ }^{20}$ It must be remembered that, except for smoking opium, which had long been contraband, ${ }^{21}$ there were no effective controls on any part of the traffic in drugs prior to $19 \mathrm{r}^{2} .{ }^{22}$ Addicted persons who sought comfort or intoxication could buy whatever they wanted from any supplier, at moderate prices; ${ }^{23}$ and those who wished to avail themselves of medical care could apply to any member of the profession ${ }^{24}$ for any indicated treatment, including gradual withdrawal or even a permanent "comfort" regime. ${ }^{25}$ On its face, therefore, the Harrison Act seemed better designed to bring the traffic into observable and controllable channels ${ }^{20}$

${ }^{16}$ See Ansuinger and Tompkins, op. cit. sttpra note 12, c. 4; Senate Committec on the Judiciary, supra note 7 , at 4 .

${ }^{17}$ For many years, the mainstay of the illicit traffic has been heroin; crude opium and laudanum have all but disappeared, cocaine is rare, and diversions of morphine and synthetics such as methadone into illicit channels are not encountered on a significant scale. See MAURER AND Vocel, op. cit. supra note 1 , c. 2; Anslinger and Tomprins, op. cit. supra note I2, c. 2.

${ }_{18}$ Act of Dec. 17, I914, c. I, 38 STAт. 785, as amended, 26 U. S. C. $\$ \$ 4701-36$ (Supp. III, 1956).

${ }^{10}$ See H. R. Rep. No. 23, 63d Cong., Ist Sess. (1913); S. Rep. No. 258, 63d Cong., 2d Sess. (1914); H. R. REP. No. I196, 63d Cong., 2d Sess. (1914).

${ }^{20}$ The act narrowly escaped the bar of unconstitutionality in its first and only direct test before the Supreme Court. United States v. Doremus, 249 U. S. 86 (1919).

${ }^{21}$ Smoking opium was subject to prohibitively high duties during most of the nineteenth century, sec TERRY AND Pellens, op. cit. supra note 2, at 536-39; its domestic manufacture was taxed after 1890, Act of Oct. 1, 1890,26 Srst. 620, 26 U. S. C. $\$ 4711$ (Supp. III, 1956); and its importation was prohibited after 1909. Act of Feb. 9, 1909, 35 ST^т. 614, 21 U. S. C. $\$ 173$ (1952). The 1909 act was drastically revised, Act of Jan. I7, 19r4, 38 STAT. 275, by the same Congress that passed the Harrison Act.

22 See Maurer AND Voger, op. cit. supra note 1 , at 191-92.

${ }^{23}$ Morphine, for example, cost "in the neighborhood of 60 cents for a drachm [60 grains] . . . when sold in original bottles or large fractions" at retail drugstore prices in 1913. TERRY and Pellens, op. cit. supra note 2 , at 27 .

24 Physicians, along with promoters of narcotic-laden patent medicines, were accused of substantial responsibility for the spread of addiction during this period. In 1898 , for example, heroin had been presented as a new wonder-drug free of the addicting properties of morphine and the other opiates, and its indiscriminate use by the medical profession produced many new addicts. Sce TEnRY AND Pellens, op. cit. supra note 2 , at 68 et seq.

${ }^{25}$ In some instances, habitual users were even provided with sustaining dosages by public health authorities to prevent them from running afoul of local prescription laws. See Charles E. Terny, Annual Report, Bonrd of Health, Jacksonville, Fla. (1913); Brown, Enforcement of the Tennessee Anti-Narcotic Latw, 5 AM. J. PuB. Health 323 (1915).

${ }^{20}$ Dr. Hamilton Wright, member of the American Opium Commission and vigorous supporter of the Harrison Act, described its similar forerunner in the Sixty-first Congress (H.R. 25241) as follows: "It is designed to place the entire interstate traffic in the habit-forming drugs under the administration of the Treasury Department. It is the opinion of the American Opium Commission that it would bring this whole traffic and the use of these drugs into the light of day and thereby create a public opinion against 
than to repress all nonmedical uses by transforming a large group of hitherto lawabiding citizens into felons.

The heart of the act is an excise tax, imposed at the rate of one cent per ounce, ${ }^{27}$ on opium, isonipecaine, coca leaves, and other opiates and their derivatives, ${ }^{28}$ to be evidenced by stamps affixed to the package or container and payable by the importer, manufacturer, producer, or compounder-i.e., the first domestic handler. Other provisions operate, in theory, at least, to facilitate the collection of this not-tooexorbitant impost. Thus, it is unlawful for anyone to purchase, sell, dispense, or distribute any narcotic drugs, unless he does so in or from the original stamped package. $^{29}$ It is also unlawful for anyone to sell, barter, exchange, or give away such drugs, except pursuant to a written order from the recipient, prepared on special forms supplied by the Treasury Department. ${ }^{30}$

Persons in any vocation involving the handling of narcotic drugs-e.g., importers, manufacturers, wholesalers, pharmacists, doctors, dentists, researchers, etc.-also are required to register with the Treasury Department and pay an occupational tax graduated from one to twenty-four dollars. ${ }^{31}$ Registrants are required to keep records, available at all times for inspection by law-enforcement officers, and to file returns as required by the Secretary of the Treasury. ${ }^{32}$

In I937, marijuana was subjected to a similar pattern of control, ${ }^{33}$ except that the tax rate was prohibitory-one dollar per ounce on any transfer of marijuana to any person registered under the provisions of the act, and one hundred dollars per ounce on any transfer to an unregistered person. ${ }^{34}$

It will readily be observed that this pattern provides the strictest kind of controls . for the so-called legitimate traffic in drugs-i.e., for whatever supplies are permitted to pass through the regulated channels, covered by the Harrison Act. The registration and return provisions assure that all legitimate traffickers are known to the authorities, while the revenue stamps, the official transfer forms, and the records required to be kept at each stage bring each individual transaction into plain view for official scrutiny. Moreover, to facilitate enforcement, the complexity of this pattern has been exploited to multiply penalties and sanctions: besides the general tax-law provisions which punish evasion-failure to file returns, fraud, counterfeiting of stamps, and the like $\mathrm{s}^{\mathbf{3 5}}$-the mere possession of drugs in unstamped con-

the use of them that would be more important, perhaps, than the act itself." Hearings before the House Ways and Means Committee, 6rst Cong., 2d Sess. 49-50 (1910).

${ }_{27} 38$ STAT. 785 (1914), as amended, 26 U. S. C. \$470I (Supp. III, 1956).

${ }^{28} I d$. $\$ 473 \mathrm{I}$ (a). To this list, the Secretary of the Treasury may add new substances found to have opium-like addicting liability. Id. $\$ 473 \mathrm{I}(\mathrm{g})$.

${ }^{20} 1 d . \$ 4704$.

${ }^{30}$ Id. $\$ 4705$.

${ }^{31}$ Id. $\$ 472 \mathrm{I}-22$.

${ }^{32}$ Id. $\$ 4732$.

${ }^{33}$ Act of Aug. 2, 1937, 50 STAT. 554, 26 U. S. C. $\$$ 4741-62 (Supp. III, 1956).

${ }^{34} \mathrm{Id}$. $\$ 474 \mathrm{I}$. These taxes must be paid in advance by the intended transferee at the time of securing the prescribed order form from the Treasury Department.

${ }^{\mathrm{a}}$ See 26 U. S. C. $\$ \$ 720 \mathrm{I}-\mathrm{I} 2$ (Supp. III, 1956). 
tainers is "prima facie evidence of a violation"; ${ }^{36}$ drugs in unstamped containers are subject to seizure and forfeiture; ${ }^{37}$ any act requiring registration-i.e., any "trafficking" without registering-is made a separate offense, independent of the failure to register per se; ${ }^{38}$ and the act of transporting drugs is a crime for any person not registered or protected by certain specific exemptions-e.g., common carriers, employees of registrants, public officials acting in the scope of their duties, etc. ${ }^{30}$

During its entire four decades, the Harrison Act has been an unqualified success as a strictly regulatory measure. ${ }^{40}$ Its weaknesses and failures show up only in its repressive applications, where it has been sweepingly invoked as a prohibition enactment. ${ }^{41}$ By diligent police work, the authorities have seen to it that narcotic drugs, once lawfully imported and consigned to registered distributors and dispensers, rarely go astray, even in minute quantities; but they have never been able to cope with the enormous flow of smuggled drugs that are distributed to addict-consumers without ever entering the regulated channels at all. ${ }^{42}$

Perhaps these forty years of failure have also been forty years of error. There is authority-including emphatic support from the courts-for the proposition that addicts were never intended to be pushed outside the regulatory framework, as Congress envisaged it in passing the act. ${ }^{43}$ They might, as reasonably, have been expected, instead, to address themselves to the medical profession for help. ${ }^{44}$ The statutory language is susceptible of differing interpretations as to its effects on medical practitioners, and this is what has led to uncertainty as to its prohibitory scope. If it be conceded that all supplying of drugs to addict-consumers-i.e., uncontrolled sales by unlicensed and unregistered persons-was to be ended, there yet remained the question whether doctors might not take care of their addict-patients by prescribing or administering as the doctors deemed necessary.

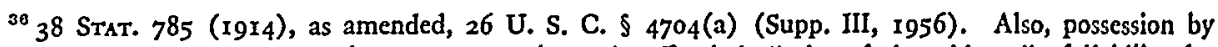
any unregistered person, even when stamps are properly affixed, is "prima facie evidence" of liability for the tax, thus furnishing a basis for prosecution for evasion. Id. $\$ 4724(\mathrm{c})$.

${ }^{37}$ Id. $\$ 4706$. The vessel or vehicle used to transport seizable drugs may also be subject to forfeiture, 64 STAT. 427,49 U. S. C. $\$ 78$ I (I952).

${ }^{38} 38$ STAT. 785 (1914), 26 U. S. C. $\$ 4724$ (a) (Supp. III, r956).

s9 Id. $\$ 4724$ (b).

${ }^{\text {to }}$ See Comment, supra note 14 , at $77 \mathrm{I}$.

${ }^{41}$ Like the Marihuana Act, supra note 33, the Smoking Opium Act, stupra note 21, imposes a tax with rates that are exclusively prohibitory-i.e., \$300 per lb.

\$2 Prior to World War II, smuggling was by the "cargo" method, and "seizures involving 2000 pounds of opium, and 6000 ounces of heroin were not uncommon." Ansiinger aNd Tompkins, op. cit. supra note 12, at 143. Recently; the flow has continued in kilo and ounce quantitics. A kilo of pure heroin (costing perhaps $\$ 1500$ at shipside abroad) will make upwards of 100,000 "caps" or "decks," worth several dollars each in the illicit retail market in the United States. See Hearings before the Senate Special Committee to Investigate Organized Crime in Interstate Commerce, 82d Cong., 1st Sess., pt. 14, at 422-24 (195I). An ounce of heroin is less bulky and more concealable than a pack: of cigarettes. See also Hearings, supra note 6 , pt. I, at $36 \mathrm{et} \mathrm{seq.}$

${ }^{43}$ The legislative history of the act is unilluminating as to congressional intent. Sce notes 19 and 26 stipra, and note 93 infra. See also MaURER AND Vogel, op. cit. silpra note 1 , at 21.

"See Terry and Pellens, op. cit. supra note 2, at 85. In 1918, it was cstimated, on the basis of a survey by questionnaires, that nearly 240,000 addicts were under the direct care of physicians. Special Committee of Investigation, U. S. Treasury Dep't, The Traficic in Narcotic Drugs 3 (rorg). 
Physicians, dentists, and veterinary surgeons ${ }^{45}$ who are "lawfully entitled" to dispense drugs ${ }^{46}$ must register ${ }^{47}$ and keep records ${ }_{3}^{48}$ but they may prescribe or administer drugs without making use of the written Treasury Department order form, ${ }^{49}$ and without regard for the original-stamped-package requirement. ${ }^{50}$ And persons possessing drugs obtained pursuant to a prescription, or received directly from a registered practitioner, are excepted from the general prohibitions against transportation $^{51}$ and possession. ${ }^{52}$ But difficulty arises from the fact that every one of these exemptions and exceptions is qualfied with language that implies additional limitation. Thus, the prescription specified exempts the recipient only if it is "issued for legitimate medical uses. ..." ".63 And the direct dispensing similarly exempted is covered only when it is "to a patient by a registered physician ... in the course of his professional practice," and where said drugs are dispensed or administered to the patient "for legitimate medical purposes. ..."54 Similarly, the language which excuses medical practitioners from the order-form requirement covers dispensing "to a patient by a physician ... in the course of his professional practice only ...," makes it expressly unlawful for any person, including practitioners, to obtain drugs "for any purpose other than the use, sale, or distribution thereof by him ...." in the legitimate practice of his profession. ${ }^{56}$ Even the exemptions which permit interstate transportation of drugs by persons who have received them on prescription or by direct dispensation from a physician specify that the prescription must have been "issued for legitimate medical uses" and the dispensation must have been "to the patient for legitimate medical purposes." session by unregistered persons uses different phrasing: the drug must have been "prescribed in good faith." exemptions for transfers by a registered medical practitioner "in the course of his professional practice only" and by a pharmacist if "made in good faith" in pursuance of a prescription. ${ }^{59}$

\footnotetext{
\$5 The phrase "and other practitioners" has recently been added to remove doubts about the status of licensed persons in fields such as osteopathy. Act of Aug. 31, 1954, c. II 47, 68 STAT. roor.

${ }^{16} 38$ STAT. 785 (r9I4), as amended, 26 U. S. C. $\$ 472$ I (4) (Supp. III, 1956). This provision, thus, wisely ties the act to state laws for a determination of each applicant's qualifications and right to practice. Burke v. Kansas City Osteopathic Ass'n, III F. 2d 250 (roth Cir. 1940). See also Perry v. Larson, I04 F. 2d 728 (5th Cir. 1939).

${ }^{47} 3^{8}$ Star. 785 (rgr4), as amended, 26 U. S. C. $\$ 4722$ (Supp. III, I956).

48 Id. $\$ \$ 4702(\mathrm{a}), 4704,4705$. $\quad{ }_{40}$ Id. $\$ 4705(\mathrm{c})(\mathrm{I}),(\mathrm{z})$.

${ }^{\text {co } I d . ~} \$_{4704}(\mathrm{~b})$.

og Id. $\$ 4724$ (c).

¿Id. $\$ 4704$ (b) (2).

${ }^{51}$ Id. $\$ 4724$ (b) (5), (6).

${ }^{53}$ Id. $\S 4704(\mathrm{~b})(\mathrm{I})$.

${ }^{55} \mathrm{Id}$. $\$ 4705(\mathrm{c})(\mathrm{I})$.
}

${ }^{80}$ Id. $\$ 4705(\mathrm{~g})$. But this provision is unconstitutional. Blunt v. United States, 255 Fed. 332 (7th Cir. 1918), cert. denied, 249 U. S. 608 (1919).

${ }^{67} 38$ StAT. 788 (I914), as amended, 26 U. S. C. $\$ 4724$ (b)(5), (6) (Supp. III, I956). These provisions apparently charge the recipient with responsibility for the bona fides of the doctor prescribing or dispensing to him, but no cases testing such a bizarre extension have been found.

${ }^{80}$ Id. $\$ 4724(\mathrm{c})$.

${ }^{80} 50$ STAT. 554 (1937), 26 U. S. C. $\$ 4742$ (b)(1), (2) (Supp. III, I956). This latter subsection, incidentally, makes the druggist answerable for any prescription where he may be charged with knowledge of the prescribing doctor's bad faith-thus, effectively cutting off all sales of marijuana, in as much as it has no currently recognized medicinal value. 
What did the lawmakers intend when they selected all these qualifying phrases? Who was to decide what constituted "legitimate medical purposes," set the bounds of "professional practice only," pass on the practitioner's "good faith," and determine whether he had departed from "the legitimate practice of his profession"? At the outset, the questions were not sharply put..$^{60}$ The nation was absorbed in World War I, and the Treasury Department seemed content to let the new regulatory pattern emerge slowly. But in r919, the lull ended, and a veritable blitz commenced. A special Treasury Department committee stunned the nation with a report that one million persons had become addicted to "dope," mostly young people, many "under the age of 20."11 And in I920, the Narcotics Division of the Treasury Department was merged into the lusty new Prohibition Unit, then launching its roistering crusade against liquor-drinkers and bootleggers. ${ }^{02}$

The first point of attack was necessarily the medical profession. While reputable doctors accepted the addict's affliction as one within the purview of the Hippocratic Oath, there could be no wholesale roundups and headline-making arrest records-nor, incidentally, could the sinister "dope ring" of later chronicles make its appearance. ${ }^{03}$ If the addict remained a "patient" he could bargain for help, albeit on rigorous terms, with those who understood his problem and could aid him most-and no sacrifice in the cause of therapy could have approached the cruel enslavement that was to follow later, when his only bargain was with the illicit peddler, on the latter's terms. Medical men were aware of this responsibility, and, by and large, they were responsive to it, until the early twenties. Then, they were driven into full retreat by a series of Supreme Court decisions that still record one of the most astonishing occurrences in our legal history. The High Court was the victim of a trick.

On the same day on which the constitutionality of the Harrison Act was affirmed, ${ }^{64}$ the Court handed down the first of the "doctor" cases, Webb v. United States, in which the Government had posed the following certified question: ${ }^{05}$

\footnotetext{
${ }^{\circ 0}$ See, e.g., Tucker v. Williamson, 229 Fed. 201 (S.D. Ohio 19r5); United States v. Curtis, 229 Fed. 288 (N.D. N.Y. 1916); United States v. Friedman, 222 Fed. 276 (W.D. Tenn. 1915).

${ }^{61}$ Special Committee of Investigation, op. cit. supra note 44 , at 6 . Other estimates of the same period ran as high as 5,000,000. See Terry and Pellens, op. cit. stipra note 2, at 3 . The most impressively responsible study estimated "somewhat less than 215,000" for the beginning of the period 1915-22, and "about $x x 0,000$ " for the end of that period. Kolb and Du Mez, The Prevalence and Trend of Drug Addiction in the United States and Factors Influencing It, 39 PuB. Healtu Rep. I179 (1924). Even in those days, the Narcotics Division was somewhat aggressive about its own views; on May 4, I924, just before publication of the Kolb-Du Mez study, a Prohibition Unit press release was issued, stating: "It is estimated that there are upwards of 500,000 drug addicts in the United States. . . ." Terry and Pellens, op. cit. supra note 2, at 43 n. 25 .

${ }^{\circ}$ See Laurence F. Schmeckebier, The Bureau of Prohibition 3 et seq. (Service Monograph No. 57, Institute for Government Research, Brookings Institute 1929).

"The illicit traffic took an exotic cast from the Chinese opium smugglers, opium "dens," dime-novel fantasies of the period, and association with the oriental "tongs," the Mafia, and similarly chimerical organizations. Contemporaries, however, recognized the peddler as an understandable, if lamentable, product of the new enforcement policies: "Thus was an illegal substitute for the legal channels of supply created by the law because the law was so interpreted and administered as to render the registered distributors uncertain of their status." TERRY AND POLLENS, op. cit. supra note 2, at 91.

os United States v. Doremus, 249 U. S. 86 (rgrg).

${ }^{65} 249$ U. S. 96, 99 (1919).
} 
If a practicing and registered physician issues an order for morphine to an habitual user thereof, the order not being issued by him in the course of professional treatment in the attempted cure of the habit, but being issued for the purpose of providing the user with morphine sufficient to keep him comfortable by maintaining his customary use, is such order a physician's prescription under exception (b) of $\$ 2 ?^{66}$

And the Justices responded: ${ }^{67}$

[T]o call such order for the use of morphine a physician's prescription would be so plain a perversion of meaning that no discussion of the subject is required.

Two extraneous facts doubtless influenced the Court's response: at this time (IgI9), public hysteria about the "dope menace" was thoroughly whipped up; and the case was one of flagrant abuse (Dr. Webb had sold prescriptions by the thousands, indiscriminately to any applicant, for fifty cents apiece).$^{68}$

The second case, Jin Fuey Moy v. United States, ${ }^{69}$ also arose out of an outrageous set of facts: the doctor had written prescriptions for morphine by the gram, for all comers, at one dollar per gram. The Court sustained his conviction, holding: ${ }^{\mathbf{7 0}}$

Manifestly the phrases "to a patient" and "in the course of his professional practice only" are intended to confine the immunity of a registered physician, in dispensing the narcotic drugs mentioned in the act, strictly within the appropriate bounds of a physician's professional practice, and not to extend it to include a sale to a dealer or a distribution intended to cater to the appetite or satisfy the craving of one addicted to the use of the drug.

Next came the case that contained the joker, United States v. Behrman, decided March 27, 1922..$^{71}$ Here, too, the abuse was flagrant. Dr. Behrman had given a known addict, at one time and for use as the addict saw fit, prescriptions for ${ }^{50}$ grains of heroin, 360 grams of morphine, and 210 grams of cocaine. But the indictment was drawn so as to omit any accusation of bad faith; it charged, in effect, that this treatment was for the purpose of curing the addict, ${ }^{72}$ and, thus, its validity depended on a holding that prescribing drugs for an addict was a crime, regardless of the physician's intent in the matter. The District Court sustained a demurrer, and the Government invoked its right to appeal directly to the Supreme Court. ${ }^{73}$

\footnotetext{
${ }^{\circ 0}$ Note how the question is phrased to set "professional treatment in the attempted cure of the habit," on the one hand, against prescribing "to keep him comfortable by maintaining his customary use," on the other. The result was to establish that the latter was not "professional treatment" at all.

or Id, at 99-roo.

${ }^{68}$ So the certified question put to the Court also departed widely from the facts of the case; this was not a responsibly administered "comfort" regime-this doctor was a mere peddler.

${ }^{00} 254$ U. S. 189 (1920).

T0 Id. at I94.

${ }^{71} 258$ U. S. 280 (1922). It is noteworthy that the medical profession itself had been urging a clarification of the earlier decisions by means of a test case. A special A.M.A. committec met with Department of Justice officials early in I92I to confer "as to the practicability of obtaining decisions from the United States Supreme Court which will remove existing uncertainties as to the meaning and application of the provisions of the Harrison Law." Committee on Narcotic Drugs, Council on Health and Public Instruction, Report, 76 A. M. A. J. 1669, 1670 (1921).

${ }_{72}$ The indictment is extensively paraphrased by the Court. 258 U. S. at $286-87$.

${ }^{73} 18$ U. S. C. $\$ 373$ I (1952).
} 
A majority of the justices, no doubt moved by the flagrant facts, which they set forth fully in the opinion, ${ }^{74}$ ruled that the indictment was good. Three dissented tersely: ${ }^{75}$

It seems to me wrong to construe the statute as creating a crime in this way without a word of warning. Of course the facts alleged suggest an indictment in a different form, but the Government preferred to trust to a strained interpretation of the law rather than to the finding of a jury upon the facts. I think that the judgment should be affirmed.

The dissenters, besides Holmes, who wrote for them, were Justices Brandeis and McReynolds.

Armed with what came to be known as the Behrman indictment, the Narcotics Division launched a reign of terror. Doctors were bullied and threatened, and those who were adamant went to prison..$^{76}$ Any prescribing for an addict, unless he had some other ailment that called for narcotization, was likely to mean trouble with the Treasury agents. The addict-patient vanished; the addict-criminal emerged in his place. Instead of policing a small domain of petty stamp-tax chisellers, the Narcotics Division expanded its activities until it was swelling our prison population with thousands of felony convictions each year. ${ }^{77}$ Many of those who were caught had been respected members of their communities until the T-men packed them off. $^{78}$

In short order, however, the Behrman ruling found a challenger. Dr. Charles O. Linder, after a lifetime of honorable practice in Spokane, Washington, was induced by one of the Division's odious addict-stool-pigeons to write a prescription for four small tablets of cocaine and morphine. ${ }^{79}$ Several agents thereupon descended on his office, conducted a rowdy search, and dragged him off to jail. ${ }^{80} \mathrm{He}$ was indicted in the Behrman form, convicted, sentenced, and lost on his appeal to the Circuit Court of Appeals. ${ }^{81}$ But he carried the fight on to the Supreme Court, where he was completely vindicated. ${ }^{82}$ The opinion, unanimous this time and written by Justice McReynolds, set forth what is still the controlling interpretation of the Harrison Act: ${ }^{83}$

${ }^{74} 258$ U. S. at $288-89$.

${ }^{75} \mathrm{Id}$. at 290 .

${ }^{70}$ See Manning v. United States, 287 Fed. 800 (8th Cir. 1923); Hobart v. United States, 299 Fed. 784 (6th Cir. 1924); Simmons v. United States, 300 Fed. 32I (6th Cir. 1924).

${ }_{77}$ A 1928 census of federal prisoners (in federal institutions) revealed that in this heyday of Prohibition, there were two prisoners serving sentences for narcotic-drug-law offenses for every one incarcerated for a liquor-law violation. The former constituted one-third of the total prison population (2529 out of 7138). SCHMECKEBIER, op. cit. stupra note 62, at 143 .

${ }^{78}$ See TerRy and. Pellens, op. cit. supra note 2, c. 8.

${ }^{79} \mathrm{Dr}$. Linder claimed she had told him only that she was in great pain from a stomach ailment and her regular physician was unavailable; she said she had disclosed that she was an addict. Transcript of Record, Linder v. United States, 268 U. S. 5 (1925).

${ }^{80}$ See Motion to Quash Search Warrant, Transeript of Record, Linder v. United States, 268 U. S. 5 (1925).

${ }^{81}$ Linder v. United States, 290 Fed. 173 (9th Cir. 1923).

${ }^{82}$ Linder v. United States, 268 U. S. 5 (1925).

${ }^{83} 1 d$. at 18 (emphasis added). 
The enactment under consideration levies a tax, upheld by this court, upon every person who imports, manufactures, produces, compounds, sells, deals in, dispenses or gives away opium or coca leaves or derivatives therefrom, and may regulate medical practice in the States only so far as reasonably appropriate for or merely incidental to its enforcement. It says nothing of "addicts" and does not undertake to prescribe methods for their medical treatment. They are diseased and proper subjects for such treatment, and we cannot possibly conclude that a physician acted improperly or unwisely or for other than medical purpose solely because he has dispensed to one of them, in the ordinary course and in good faith, four small tablets of morphine or cocaine for relief of conditions incident to addiction.

The Court warned that its opinions in the Webb and Jin Fuey Moy cases should be narrowly limited to the facts there involved, and then it dismissed the Behrman case (and blasted at the Behrman indictment) in the following strong disclaimer: ${ }^{84}$

This opinion related to definitely alleged facts and must be so understood. ... The opinion cannot be accepted as authority for holding that a physician who acts bona fide and according to fair medical standards, may never give an addict moderate amounts of drugs for self-administration in order to relieve conditions incident to addiction. Enforcement of the tax demands no such drastic rule, and if the Act had such scope it would certainly encounter grave constitutional difficulties.

But by 1925 , it was too late to change the pattern. The trick had worked. The doctors had withdrawn, and they never permitted the addict to reapproach them. ${ }^{\mathbf{8 5}}$ The peddler had taken over, and his profits soared as enforcement efforts reduced his competition and drove his customers ever deeper into the underworld, where they were easy prey. It is significant that the present-day regulation of the Narcotics Bureau advising doctors of their rights in dealing with addicts blithely ignores what the Supreme Court said in the Linder case ${ }^{86}$ and still paraphrases the discredited language of Webb v. United States: ${ }^{87}$

An order purporting to be a prescription issued to an addict or habitual user of narcotics, not in the course of professional treatment but for the purpose of providing the user with narcotics sufficient to keep him comfortable by maintaining his customary use, is not a prescription within the meaning or intent of the Act; and the person filling such an order, as well as the person issuing it, may be charged with violation of the law.

Simultaneously with its campaign to cut the addict off from recourse to medical help, the Narcotics Division launched an attack on him along another line as well. He was portrayed as a moral degenerate, a criminal type, and the public was told that he could only be dealt with by being isolated from all normal contacts with society; if left at large, one of his main preoccupations was allegedly contriving ways to induce others to share his misery by becoming addicted themselves. In short, he

st Id. at 22 (emphasis added).

B5 "In other words, a physician treating cases of this nature is not safe from unwarranted indictment and may be called upon at any time in court to prove his innocence to the detriment of his social, professional, and economic standing. ..." TeRrY and Pellens, op. cit. supra note 2, at 77r.

${ }^{80}$ Linder v. United States, 268 U. S. 5 (1925).

${ }^{87}$ U. S. Treas. Dep't, Bureau of Narcotics Reg. 5, art. 167 (1949), 26 C. F. R. $\delta$ I51.167 (1949). 
should be caught and locked up. ${ }^{88}$ A formal action taken by the American Medical Association in I924 is still cited as official concurrence by the doctors in this viewpoint. ${ }^{89}$ But it is more likely that here, also, the zeal of the enforcement authorities led them to overstretch the limits of reasonable interpretation.

At its annual meeting in I919, the House of Delegates of the American Medical Association had passed two resolutions, one calling on the Commissioner of Internal Revenue to organize a nation-wide conference "with a view to controlling the traffic in and harmful consumption of narcotic drugs," and the other creating a special four-man committee to study the entire situation and report back to the House.90 The latter committee reported the following year, recommending, inter alia, that heroin be totally eliminated from all medical preparations and use, and that "the ambulatory treatment of drug addiction ... be emphatically condemned."11 The committee was referring to the prescribing of drugs to addicts for self-administration at the addict's convenience and out of the doctor's supervisory control. The word "ambulatory," however, also implied being physically at liberty instead of hospitalized or imprisoned. The text adopted by the I924 resolution was: ${ }^{22}$

Your committee desires to place on record its firm conviction that any method of trentment for narcotic drug addiction, whether private, institutional, official or governmental, which permits the addicted person to dose himself with the habit-forming narcotic drugs placed in his hands for self-administration, is an unsatisfactory treatment of addiction, begets deception, extends the abuse of habit-forming narcotic drugs, and causes an increase in crime. Therefore your committee recommends that the American Medical Association urge both federal and state governments to exert their full powers and authority to put an end to all manner of such so-called ambulatory methods of treatment of narcotic drug addiction, whether practiced by the private physician or by the so-called "narcotic clinic" or dispensary.

In the opinion of your committee, the only proper and scientific method of treatung narcotic drug addiction is under such conditions of control of both the addict and the drug, that any administration of a habit-forming narcotic drug must be by, or under the direct personal authority of the physician, with no chance of any distribution of the drug of addiction to others, or opportunity for the same person to procure any of the drug from any source other than from the physician directly responsible for the addict's treatment. The doctors, thus, were saying that the administering and dispensing of drugs ought to be-strictly controlled by themselves. The authorities, however, twisted this to

${ }^{88}$ See, e.g., U. S. Treas. Dep't, Pro-Mim. No. 217 , Oct. 19, rg2I (quoted in Terry and Pallens, op. cit. supra note 2, at 548): "This Bureau has never sanctioned or approved the so-called reductivc ambulatory treatment of addiction, however, for the reason that where the addict controls the dosage he will not be benefited or cured. Medical authorities agree that the treatment of addiction, with a view to effecting a cure, which makes no provision for confinement while the drug is being withdrawn, is a failure, except in a relatively small number of cases where the addict is possessed of a much greater degree of will power than that of the ordinary addict."

${ }^{80}$ See Bureau of Narcotics, U. S. Treasury Dep't, Memorandum Regarding Narcotic Clinics, Their History and Hazards 4 (1938), Bureau of Narcotics, U. S. Treasury Def't, Narcotio Cuinics in the United States 2-3 (1955); Anslinger and ToMpkins, op. cit. supra note 12, at 275.

${ }^{0}$ See Amertcan medical Association, Actions of the House of Del.egates and Board of Trustees Concerning Narcotics and Narcotic addiction 2 (1956).

${ }^{81}$ Committee on the Narcotic Drug Situation, Report, 74 A. M. A. J. 1324, 1328 (1920).

92 Amertcan Medrcal Association, op. cit. supta note 9o, at 7-8. 
mean that addicts undergoing treatment ought to be strictly controlled by the authorities-i.e., incarcerated..$^{93}$

The reference to "narcotic clinic" in the last quotation requires explanation. Between IgI2 and I923, a substantial number of medical men and public health officials tried to counter the assaults being made on narcotic addicts by the establishment of private or public-sponsored narcotics dispensaries. These varied widely in the details of their operation and the quality of their programs, but their aim was to provide a controlled supply for addicts who suddenly found themselves cut off by the new federal statute and the Treasury Department's vigorous enforcement campaign. In some instances, the clinic personnel tried to rehabilitate applicants and effect cures; but the main emphasis was on meeting the immediate needs of addicted persons who would otherwise be driven into the developing illicit market or end up in prison. Such institutions were opened in some forty cities throughout the country, ${ }^{94}$ and some, at least, were acknowledged by contemporary observers to be successful, ${ }^{95}$ though it is charged that some quickly degenerated into simple peddling operations, distributing drugs haphazardly to all applicants.

The clinic experiments, good and bad alike, came to an abrupt end in the early I920's, however, when Treasury agents closed on them, threatening federal prosecutions. $^{90}$ Many details of these experiments and their history are now obscured. Treasury spokesmen, echoed by United States Public Health Service officers, have missed no opportunity to attack the clinic concept as impracticable, immoral, and downright subversive. ${ }^{97}$ Since 1923 , there has been no attempt to revive any public facility for the treatment of addicts on an out-patient basis. The federal hospitals at Lexington, Kentucky, and Fort Worth, Texas, authorized in $1929,{ }^{98}$ are admirable

${ }^{03}$ Some of the doctors added to the confusion. See, e.g., Committee on Narcotic Drug Addiction, American Public Health Association, Report, II J. AM. PuB. Health Ass'N 1066 (Ig2I) (quoted in Terry and Pellens, op. cit. stipra note 2, at 897): "The group of addicts variously spoken of as criminals, degenerates, and feeble-minded is unwilling and unable to cooperate in the necessary treatment, and should be kept under official control. In the opinion of your Committee, the control of this group is essentially a police problem." But cf. Collins, Report of the Committee on the Drug Evil, in PRoceedings of the Thurteenth Annual Conference of the New York State Association of Magistrates (1922) (quoted in TerRY and Pellens, op. cit. stspra note 2, at 857): ". . one cannot conceive of a situation that would enable a Federal prohibition commissioner or an internal revenue collector to substitute their rulings for an act of Congress, to supersede the powers of Congress and legislative enactment which must necessarily receive the approval of the President, and which would even then be open to serious question, if forbidding treatment under certain conditions, as to constitutionality in infringing on the power reserved to states. Yet, it may be said, that the effect of the rulings has gone almost to this extent."

${ }^{04}$ See Comment, supra note 14, at 784 (1953); Hearings, supra note 6, pt. 5, at I870.

${ }^{0}$ See Terry and Pellens, op. cit. supra note 2 , at $850-76$.

${ }^{00}$ Dr. L. M. Powers, Health Commissioner of Los Angeles (quoted in Terry aNd Pellens, op. cit. supra note 2, at 875): "I have not been able to realize the actual purpose of the closing of our clinic for there has been some unseen motive prompting much opposition to clinics which $I$ have not been able to comprehend." See Stevens, supra note 2, at 43 ; Hearings, supra note 6, pt. 5, at I459 n. I.

${ }^{07}$ See, e.g., testimony of Commissioner Anslinger, Hearings, supra note 6, pt. I, at 44-47; Senate Committee on the Judiciary, Treatment and Rehabilitation of Narcotic Addicts, S. REP. No. I850, 84th Cong., 2d Scss. 2-1I (1956); Hearings before the Senate Special Committee to Investigaie Organized Crime in Interstate Commerce, $82 \mathrm{~d}$ Cong., Ist Sess., pt. I4, at 228 (I95I).

${ }^{88} 45$ STAT. 1085 (1929), 42 U. S. C. $\$ 257$ (1952). 
centers for withdrawal and rehabilitation of federal-prisoner addicts and those who submit voluntarily for treatment; but both are dedicated to the principal of absolute isolation as a sine qua non of therapy..$^{80}$

In the early thirties, a doctor in Seattle opened a private clinic to furnish narcotic drugs to addicts. He observed the crucial distinction between direct administration to each patient, and prescribing or dispensing in quantity so that the drugs might be overindulged or resold; he administered directly only. But he promptly attracted the attention of the Narcotics Bureau. He was first indicted in May r934 and was acquitted after a full jury trial.100 Thereafter, he continued his operations under the hostile surveillance of Narcotics Bureau agents, who made a second case against him, resulting in another indictment, in November 1935. This time, he was convicted, sentenced to seven years, and fined $\$ 10,000$. Subsequently, pending his appeal, which resulted in affirmance, ${ }^{101}$ he gave bond and sought to continue his clinic operation. The Narcotics Bureau countered, ${ }^{102}$ however, by ordering his wholesale suppliers to refrain from selling narcotic drugs to him. He brought an action in the District of Columbia courts, to enjoin the Commissioner from thus interfering with his activities-and it was only when he lost the first round of this collateral skirmish, being denied a temporary restraining order, ${ }^{103}$ that he gave up the fight. He went to the McNeil Island Penitentiary in June 1937, and in 1938, the State of Washington Department of Licenses revoked his medical license. ${ }^{104}$

Year after year, the pattern remained the same. Addicts and small-fry peddlers ${ }^{105}$ were arrested by the thousands; ${ }^{108}$ the traffic prospered; and the overlords at the

${ }^{90}$ At Lexington, the state antiaddiction law is used to compel voluntary patients who have left once against advice to submit to virtual imprisonment if they seek readmission: they must plead guilty in the local Kentucky court, where they usually receive a one-year sentence, suspended on condition they remain in the hospital until released. See Comment, supra note $\mathrm{I} 4$, at $776 \mathrm{n}$. 151 .

${ }^{100}$ United States v. Ratigan, 7 F. Supp. 49I (W.D. Wash. 1934). See also Anszinger and Tomp. kins, op. cit. supra note 12 , at 135 .

${ }^{201}$ Ratigan v. United States, 88 F. 2d 9x9 (9th Cir. 1937), cert. denied, 301 U. S. 705 (1937).

${ }^{102}$ The Bureau's report of the matter states that even after his conviction, Dr. Ratigan remained "unregenerate" by indicating his intention to continue supplying addicts with drugs. ANSLINGER AND Tomprins, op. cit. stipra note 12, at 135-36. Commissioner Anslinger has recently characterized the relationship between his Bureau and members of the medical profession as follows: "There is complete cooperation and a feeling of confidence between the enforcement officer-he does not act like a policeman, in other words. He is more in the nature of a fatherly adviser. . . . Now and then you will find there is a weak link probably in a State; the addict gets to know a doctor who will issuo prescriptions without making too close an examination... . But he does not go too far. We always catch up with him very quickly, and certainly he is brought to heel very quickly." Hearings, sutpra note 6, pt. I, at 38 .

${ }^{103}$ See Remarks of Hon. John M. Coffee, 83 Conc. Rec. 2606 App. (I938).

${ }^{104}$ Official interest in Ratigan apparently continues: "His license has been revoked, and he has taken the medical board into court several times. I am sure he will not get his license back." (Emphasis added.) Testimony of Commissioner Anslinger, Hearings, supra note 6, pt. 5, at 1437 .

105 "Now, we often find the courts will say, "Well, now, I have here this poor drug addict. He only peddles to take care of himself.' Well, I hope the honorable Senators are not taken in with that sort of thing, because that addict will peddle a capsule or he will peddle a kilo or a thousand ounces or a ton if he can. Now, 70 percent of those we send to prison are addicts." Testimony of Commissioner Anslinger, id., pt. $\mathrm{I}$, at 40 .

${ }^{100}$ Between 1947 and 1954 , the percentage of the total federal prison population sentenced for narentics violations rose from $9 \%$ to $15.7 \%$; the combined federal, state, and local authorities made a total of 23.365 arrests for narcotics offenses in the latter year. Sce $i d .$, pt. 1 , at 12, 14. As of June 30, 
top of the illicit operations never got near "the stuff" and were rarely brought to account. ${ }^{107}$ This fantastic black market, where smuggled drugs brought thousands of times their intrinsic value, remained an exclusively American phenomenon, playing its part, along with bootlegging, in the rise of gangsters and the emergence of bigtime organized crime.

In 195x, the Kefauver Committee turned its attention to narcotics and marijuana, ${ }^{108}$ causing a flurry of public apprehension. It was alleged that drug addiction was on the increase and had captured school children and teen-agers. ${ }^{109}$ In this atmosphere, the Narcotics Bureau announced that stiffer penalties, harsher repression, and more law-enforcement efforts were the answer." Dozens of "tough" measures were introduced in the Eighty-first Congress by lawmakers vying for public approbation as saviors in the face of this exaggerated menace. ${ }^{111}$

The bill which eventually became law was the offering of Congressman Hale Boggs, of Louisiana. Its chief feature was mandatory minimum sentences, applicable to all narcotic drug offenses, and graduated as follows: first conviction, two to five years; second, five to ten years; and third, ten to twenty years. ${ }^{112}$ For second and subsequent offenses, the judge was prohibited from suspending the sentence or granting probation. This measure was opposed by the American Bar Association, ${ }^{113}$ and it has reportedly been ignored or defied by sentencing judges in a significant number of cases where the defendants before them seemed to merit less than the prescribed minimum punishment. But the popularity of vindictive attitudes towards anyone related to the "dope menace" evoked responses in state legislatures as well, and a number of jurisdictions have emerged with "little Boggs Acts."114

In the same wave of popular interest, new legislation was enacted in a number of jurisdictions providing for the compulsory treatment-in confinement-of ad-

1955, federal prisoners serving time for narcotics and marijuana offenses numbered 3,241 , or $14.9 \%$; the only category of offense accounting for more federal prisoners was motor-vehicle theft (2r.5\%). See U. S. Dep'T of Justice, Federal Prisons, 1955, 62-63 (1956).

${ }^{107}$ See Senate Special Committee to Investigate Organized Crime in Interstate Commerce, Final Report, S. REP. No. 725, 82d Cong., Ist Sess., 31-33 (r95I).

${ }^{108}$ See Hearings before the Senate Special Committee to Investigate Organized Crime in Interstate Commerce, 82d Cong., Ist Sess. pt. 14 (195I).

${ }^{100}$ Senate Special Committee to Investigate Organized Crime in Interstate Commerce, supra note 107, at 27. Cf., Gerrity, The Truth About the Drug Menace, Harper's Magazine, Feb. 1952, pp. 27-31.

${ }^{120}$ See Hearings, supra note 108, pt. $\mathrm{x}_{4}$, at 426-32. Cf. McCarthy, A Prosecutor's Viewpoint on Narcotic Addiction, Fed. Probation, Oct. 1943, p. 23 (reprinted and distributed by the Federal Bureau of Narcotics in 1945).

${ }^{211}$ E.g., H. R. I552, $1782,234^{0}, 2645,3539,3623,4140,4449,4512,4593,4622,4642$, and S. 1702. Several of these measures invoked the death penalty, and one (H. R. 45I2) proposed the following for enactment: "Jail sentences for convicted offenders who are the overlords and chief beneficiaries of said dope and narcotic traffic shall be increased to a maximum of one hundred years."

${ }^{112}$ Act of Nov. 2, 1851, 65 STAT. 767,21 U. S. C. $\$$ r74 (1952); cf. 68A STAT. 860, 26 U. S. C. $\S 7237$ (Supp. III, 1956).

${ }^{113}$ American Bar association Commission on Organized Crime, Organized Crime and Law Enforcement 53-55 (1952); Commission on Organized Crime, Report, 76 A. B. A. REP. 387, 4II (I95I).

11' See Tables, "Narcotic and Marihuana Penalties in the Various States," Hearings, supra note 6, pt. r, at 300-or (App.); Comment, supra note r4, at 770. Cf. Anslinger, The Federal Narcotic Laws, 6 Food Drug Cosm. L. J. 743, 748 (195I). 
dicts. ${ }^{115}$ Addiction has been made a crime per se in several states. ${ }^{110}$ In nearly every instance, however, the result has been merely to provide another statutory weapon for use against addicts, permitting apprehension and imprisonment without the formality of making a case on possession or sale. ${ }^{117}$

In February, 1955, the House of Delegates of the American Bar Association passed a resolution urging Congress "to undertake a re-examination of the Harrison Act, its amendments, and related enforcement and treatment policies and problems." 18 On March 18, I955, the Senate adopted S. Res. 67, which authorized a subcommittee of the Senate Judiciary Committee to make such a study. This subcommittee, under the chairmanship of Senator Daniel, toured the country, hearing hundreds of witnesses and amassing thousands of pages of testimony. ${ }^{110}$ Enforcement officersattorneys general, states' attorneys, sheriffs, and police chiefs in some $2500 \mathrm{com}$ munities-were also canvassed by questionnaire.

The subcommittee's conclusions were submitted in a nine-page document ${ }^{120}$ that reached two general conclusions: federal laws should be tougher, and the Narcotics Bureau should have larger appropriations. Among its specific findings were pronouncements that the current addict-population of the United States is "more . . . than all of the other western nations combined"; that thirteen per cent of this group are under twenty-one years of age; that the illicit traffic has trebled since World War $\mathrm{II} ;^{121}$ that drug addiction is responsible for fifty percent of all crime in urban areas

${ }^{118}$ Congress enacted such a measure for the District of Columbia, amid much local publicity, in 1953. Act of June 24, 1953, 67 Srat. 77, D. C. CoDE ANn. $\$ 24.60$ r et seq. (Supp. IV, 1955). The measure had been signed by the President before it was discovered that the intended places of incarceration-the USPHS hospitals at Lexington and Fort Worth-could not be used without congressional authorization. Such authority was subsequently provided, Act of May 8, I954, 68 STAT. 79, 42 U. S. C. $\$ \$ 260 a, 261$ (Supp. III, I956), but the law has proved flagrantly deficient in other particulars, sce Senate Committec on the Judiciary, Illicit Narcotics Problem in the District of Columbia, S. Rep. No. 2033, 84th Cong., 2d Sess. 3-5 (1956), and has just been revised again. Act of July 24, 1956, 70 Stat. 609. See CounciL of State Governments, Summary of State Laws Relating to the Treatment of Drug Addiction (I953).

${ }^{118}$ E.g., Kx. Rev. StAT. $\$ \$ 218.210$, 218.050 (1953); Mich. CoMp. LAws $\$ 335.154$ (Supp. I952); N. J. Stat. ANN. $\$ 30: 4$-I23.43 (1956).

117 "A startling number of those States which have legislated against drug addiction and prescribed mandatory treatment have failed to provide even the minimum facilities required for treating addicts. California is an exception, having 8 State hospitals and 12 approved private hospitals for that purpose. New Jersey, on the other hand, which has a 'model' narcotics code has no facilitics. In some States addicts may be sent to State mental hospitals, but these hospitals are not equipped to treat narcotics patients." Senate Committee on the Judiciary, Laws Controlling Illicit Narcotics Traffic, S. Doc. No. 120, 84th Cong., 2d Sess. 45 (1956).

${ }_{118}$ Proceedings of the House of Delegates, 80 A. B. A. Rep. 408 (1955).

110 The committee's hearings, supra note 6 , are published as follows: pt. I, Washington, D. C., June 2, 3, and 8, 1955; pt. 2, Philadelphia, Pa., June 17 and 18 , 1955; pt. 3, New York, N. Y., June 24 and 25, I955; pt. 4, Washington, D. C., July 12-15 and 19, 1955; pt. 5, New York, N. Y., Sept. 19-21, 1955; pt. 6, Washington, D. C., Sept. 23, 27, and 28, 1955; pt. 7, Texas, Oct. 12-21, and Dec. 14 and 15, 1955; pt. 8, California, Nov. 14-18, 1955; pt. 9, Chicago, Ill., Nov. 21 and 22, 1955; pt. 10, Detroit, Mich., and Cleveland, O., Nov. 23 and 25, 1955.

${ }^{120}$ Senate Committee on the Judiciary, supra note 7.

121 The frustrations of trying to reconcile official statistics on this subject are well illustrated by a comparison of the Narcotics Bureau's official report for 1947, BuREAU of Narcorics, op. cit. supra note 13, at 9 (1948): "The ratio of drug addicts to the general population is approximately 1 in 3,000. The increase in drug addicts since the cessation of World War II has not been as great as in previous postwar 
and twenty-five per cent of the nation's total reported crimes; ${ }^{122}$ and that drug addiction is "contagious"-i.e., addicts spread addiction "with cancerous rapidity." The subcommittee also avowed that "subversion through drug addiction is an established aim of Communist China," and that the United States is, thus, "one of the principal targets" of a communist plot "to demoralize susceptible individuals in our military services and in the general population."123

On the question of treatment for addicted persons, the subcommittee concluded that such persons should first be "removed from society"; and if treatment fails, they must be permanently consigned to "a quarantine type of confinement or isolation." I24 In a second report, ${ }^{125}$ the subcommittee blasted what it termed "the so-called clinic plan for legal distribution of narcotics [to drug addicts],"126 opining that the plan "is totally unworkable, completely contrary to accepted medical practice and theory, and would aggravate rather than solve the problem. ..." Its arguments included the familiar assault on "ambulatory" treatment, coupled with the assertion that no treatment could be effective without "hospitalization or other confinement"; that physical administration of drugs would be impracticable because of the need for frequent injections, plus the mounting "tolerance" factor; that clinics would merely supplement, not supplant, the illicit market as a source for their addict clientele; and that legalizing any distributions would create new addicts, because addiction "has the contagious qualities of a social disease." Any such plan would also be "in absolute contradiction" to our national obligations under various treaty commitments, would conflict with state laws, and would, in sum, be "a complete turnabout in our

periods," with Senate Committee on the Judiciary, supra note 7, at 2: "In spite of the fact that Federal officials have done all within their power under present handicaps and with limited personnel, the illicio drug traffic has trebled in the United States since World War II. Addicts were in the ratio of $\mathrm{I}$ to $\mathrm{r}, 000$ persons at the end of World War II. At the present time, the incidence is about I to every 3,000 persons. ..." (Emphasis as in original.)

${ }^{133}$ For the period January-June 1956, reported major crimes totaled 804,183 in areas of the United States classified as urban, and 147,776 for the rural areas. $27 \mathrm{FBI}$, U. S. DEP'T of JUsTICE, UNIForM Crime Reports for the UnIted States 5 (1956). If the senate committee's figure of 60,000 addicts in the United States is accurate, see note 7, supra, and the quoted percentages are unexaggerated, each addict must be committing, on the average, slightly more than one felony per month. Furthermore, half the urban crimes, following the F.B.I. classification, are considerably more than a fourth of the total. Accordingly, the figures are difficult to rationalize precisely on any basis.

${ }^{123}$ Senate Committee on the Judiciary, supra note 7 , at $2-4$.

124 Id. at 3 .

${ }^{235}$ Senate Committee on the Judiciary, supra note 97.

${ }^{120}$ The subcommittee devoted a part of one day, see Hearings, supra note 6, pt. 5, at I310 et seq., to statements from witnesses known to be critical of Narcotics Bureau policies, including Dr. Hubert $S$. Howe (see Howe, A Physician's Blateprint for the Management and Prevention of Narcotic Addiction, 55 N. Y. S. J. Medicine 34I (I955), Judge Jonah J. Goldstein, Dr. Andrew A. Eggston (see Berger and Eggston, Should We Legalize Narcotics, Coronet, June 1955, p. 30), Alden Stevens (see Stevens, supra note 2) and Dr. Herbert Berger (see Berger, The Richmond County Medical Society's Plan for the Control of Narcotic Addiction, 56 N. Y. S. J. Medicine 888 (1956)). Some of this testimony suggested legalizing distribution of drugs to addicts, and some of it referred to narcotics clinics as a mechanism to effect such distribution. At the subcommittee's first hearing, one of its members had characterized the sponsors of such proposals as "blecding hearts who are acting through sympathy for the poor addict"; and the chairman admitted that "it might be a little difficult for some of us to keep completely open mind on the subject." Hearings, supra note 6 , pt. I, at 44,46 . 
present policies and programs." Finally, to clinch the argument, the subcommittee affirmed its belief "that it would be absolutely immoral to give in to drug addiction and help perpetuate such pitiful conditions for the individual human being."127

The subcommittee offered a number of legislative proposals, which became law without significant opposition in the last days of the 84 th Congress. ${ }^{128}$ Without further distinguishing addicts from traffickers, the new laws raise the assessable fine for all narcotics offenses to $\$ 20,000^{128}$ and increase the mandatory minimum sentences to two, five, and ten years for successive offenses in the possession, prescription, and registration categories, ${ }^{130}$ while first sale, transfer, and smuggling offenses carry a minimum sentence of five years, which increases to ten years for all succeeding offenses. ${ }^{131}$ Special penalties apply to any sale or transfer by an adult ${ }^{132}$ to a person under eighteen: for any such offense, the minimum sentence is ten years; and if the drug is heroin, the court may impose life imprisonment or the jury may direct the imposition of a sentence of death. ${ }^{133}$

The new law directly outlaws heroin ${ }^{134}$ and contains a miscellany of special provisions to make the police work of the Narcotics Bureau easier. Customs and Narcotics Bureau agents may carry arms and may make arrests without a warrant on belief that a drug-law offense has been committed. ${ }^{135}$ Search warrants issued in connection with alleged narcotics offenses may be served at night under certain circumstances. $^{138}$ In narcotics cases, unlike other federal prosecutions, the Government may appeal from pretrial orders suppressing evidence, ${ }^{137}$ while testimony may be

${ }^{127}$ Senate Committee on the Judiciary, stapra note 97, at 3-7, 10-12. The Committee explained the intensity of this diatribe by noting that controversy over such proposals "was actually impeding law enforcement and efforts to improve and expand existing programs for the treatment and rchabilitation of drug addicts." Id. at 2.

${ }_{128}$ Pub. L. 728, 84th Cong., 2d Sess., approved July 18, 1956, 70 Stat. 567 (1956). See 102 Cono. REC. 81 I8-53, 8380-97 (daily ed. May 25 and 3x, I956).

${ }_{120}$ Pub. L. 728, 84th Cong., 2d Sess. $\$ \S 103,105-106,108,70$ STAT. 568-69, 570-71, 57x, 572 (1956). The maximum had previously been $\$ 5000$. These are not mandatory fines, but they do vest sentencing judges with ample power to tax the profits of the trafficker when an offender from the highprofit cchelons is convicted, as cumulative sentencing on multiple counts affords great flexibility.

${ }^{130}$ Id. \& 103, 70 STAT. 568 (1956). Corresponding maxima are 5, 10, and 40 years.

${ }^{131} \mathrm{lbid}$. Moreover, suspension of sentence, probation, and parolc-forms of remission of punishment potentially available to all other federal offenders-are expressly made unavailable to all but first offenders in the possession, prescription, and registration categories. Ibid.

${ }^{132}$ Early proponents of this feature neglected this distinction between adult and minor offenders, sec, e.g., S. 1702 and H. R. 1782 , 82d Cong., Ist Sess. (I95X), and would, accordingly, have subjected the latter as well to the inescapable minimum sentences contemplated by the legislation.

${ }^{18 s}$ Pub. L. 728, 84th Cong., 2d Sess. \$ 107, 70 STAт. 571 (1956).

184 Id. $\$ 201,70$ STAT. 572 (1956). Substantially the same result has been obtained by refusing all import and manufacturing licenses for heroin, so that there has been no legitimate supply available in the United States since 1925. Sce MAURER AND VoGEI, Op. cit. supra note I, at 55.

${ }^{135}$ Id. 5 ro4, 70 STAT. 570 (1956).

${ }^{230}$ Id. $\$ 201,70$ STAT. $573-74$ (1956).

${ }^{137}$ Ibid. This would have been a sound amendment of the procedure affecting all federal prosecutions, and bills to accomplish the broader purpose have been pending in every Congress since the 81st. See, e.g., S. 2060, 82d Cong., 2d Sess. (1952); S. 136 and H. R. 7404 (passed by the House of Representatives, June 7, 1954), 83d Cong., 2d Sess. (1954); H. R. 316, 84th Cong., 1st Sess. (1955). The Department of Justice requested consideration of the broader measures, but to no avail. See, Senate Committee on the Judiciary, The Narcotic Control Act of 1956, S. REP. No. 1997, 84th Cong., 2d Sess. 19 (1956). 
compelled from witnesses, despite the plea of self-incrimination, by means of a special immunity grant. ${ }^{138}$ Drug users and drug-law offenders are required, fatuously perhaps, to disclose themselves, register, and obtain a special certificate upon entering or departing from the United States ${ }^{139}$ (in peril of a penalty provision that is anything but fatuous, however: one thousand dollar fine and minimum one-year sentence). Drug addiction and drug-law violation are made grounds for deportation under the Immigration and Nationality Act. ${ }^{140}$ And to add the ultimate compounding of penalties, the new law creates a separate category of offenses (minimum two-year sentence and five thousand dollar fine) based on the use of communication facilities "in committing or in causing or facilitating the commission of, or in attempting to commit" any drug-law offense; communication facilities include "any and all public and private instrumentalities used or useful in the transmission of writings, signs, signals, pictures, and sounds of all kinds by mail, telephone, wire, radio, or other means of communication"; and "each separate use of a communication facility shall be a separate offense. ...."111

The Daniel subcommittee epitomized its philosophy, and synthesized the prevailing attitude of today's lawmakers and law enforcers, in the concluding paragraph of its report on the care of addicts: ${ }^{142}$

It should be noted that these recommendations for treatment and rehabilitation are not intended as a substitute for criminal confinement and punishment of those addicts who are convicted of law violations. They should pay their debt to society the same as non-addicts, and proper law enforcement and confinement in such instances will do much towards minimizing the narcotics traffic and addiction in the United States.

${ }^{128}$ Pub. L. 728, 84th Cong., 2d Sess. $\$ 201,70$ Srar. 573-74 (1956). Cf. Act of Aug. 20, 1954, 68 STAT. 745, I8 U. S. C. $\$ 3486$ (Supp. III, 1956), which permits such immunity grants, with rigid safeguards, in certain cases affecting the national security. The enforcement officials also sought authority to tap telephones in narcotics cases, but this was deleted when the bill reached the Senate.

${ }_{130}$ Pub. L. 728, 84th Cong., 2d Sess. $\$ 20$ r, 70 Srar. 573-74 (1956). The Treasury Department protested-to no avail-that this provision "would impose enforcement responsibilities on the Department which it could not feasibly carry out." Senate Committee on the Judiciary, supra note 137, at 24.

100 Pub. L. 728, 84th Cong., 2d Sess. $\$ 30 \mathrm{r}$, 70 STAT. 575 (1956).

141 Id. \$ 201, 70 StAT. 572-73 (1956).

${ }^{162}$ Senate Committee on the Judiciary, supra note 97, at 21. 